Corrigendum

\title{
Corrigendum to "Evaluation of Novel Stereotactic Cannula for Stem Cell Transplantation against Central Nervous System Disease"
}

\author{
Masahito Kawabori $\mathbb{D}$, Aki Tanimori, Shinri Kitta, Hideo Shichinohe $\mathbb{D}$, \\ and Kiyohiro Houkin \\ Department of Neurosurgery and Neurological Cell Therapy, Hokkaido University Graduate School of Medicine, Sapporo, \\ Hokkaido, Japan \\ Correspondence should be addressed to Masahito Kawabori; masahitokawabori@yahoo.co.jp
}

Received 26 April 2021; Accepted 26 April 2021; Published 4 May 2021

Copyright (c) 2021 Masahito Kawabori et al. This is an open access article distributed under the Creative Commons Attribution License, which permits unrestricted use, distribution, and reproduction in any medium, provided the original work is properly cited.

In the article titled "Evaluation of Novel Stereotactic Cannula for Stem Cell Transplantation against Central Nervous System Disease" [1], there was an error in Table 1, where the unit for the outer diameter and internal bore diameter columns should be corrected to " $\mu$ m." In the internal volume column, the value " $20 \mathrm{~mL}$ " should be corrected to " $20 \mu \mathrm{L}$."

The corrected version of Table 1 is as follows:

The authors confirm that this does not affect the results and conclusions of the article, and the editorial board agrees to the publication of a corrigendum. 
TABLE 1: Basic characteristics of the cannulas.

\begin{tabular}{llcccccc}
\hline & & Outer diameter & Internal bore diameter & Internal volume & Flexibility & Injection hole & Shape of the tip \\
\hline Pittsburg & Stainless steel & $890 \mu \mathrm{m}$ & $250 \mu \mathrm{m}$ & $20 \mu \mathrm{L}$ & Yes & Tip & Narrowed with open tip \\
Mizuho & Stainless steel & $1500 \mu \mathrm{m}$ & $300 \mu \mathrm{m}$ & $23.9 \mu \mathrm{L}$ & No & Side & Flattened \\
MK01 & Stainless steel & $1500 \mu \mathrm{m}$ & $300 \mu \mathrm{m}$ & $23.9 \mu \mathrm{L}$ & No & Side & Spherical \\
\hline
\end{tabular}

\section{References}

[1] M. Kawabori, A. Tanimori, S. Kitta, H. Shichinohe, and K. Houkin, "Evaluation of Novel Stereotactic Cannula for Stem Cell Transplantation against Central Nervous System Disease," Stem Cells International, vol. 2020, Article ID 4085617, 8 pages, 2020. 